\title{
Technological Public-Private Innovation Networks: A Conceptual Framework Describing Their Structure and Mechanism of Interaction
}

\author{
Rabeh Morrar
}

\author{
"Innovation is not an isolated process of individuals or firms") \\ but is the outcome of the interaction between firms, \\ customers, suppliers, competitors and various other private \\ and public organizations in a system.
}

\author{
Bengt-Åke Lundvall \\ Organizational theorist \\ In National Systems of Innovation (1992)
}

\begin{abstract}
Technological public-private innovation networks, or TechPPINs, enable cooperation between public and private actors in a complex, dynamic, social, and interactive network structure. In this article, the literature on innovation networks is used to construct a conceptual framework that describes the structure and mechanism of interaction in technological public-private innovation networks. In the framework, innovation is created through a dynamic process of interaction between the public and private actors along the network lifecycle. In each stage of network lifecycle, social capital enables various interactions to occur and different modes and quantities of knowledge and technological resources to be exchanged and reinforced. Through a combination of the product lifecycle model and social network analysis, the structure of technological public-private innovation networks are examined at each stage of the lifecycle to reveal information about how the roles of public and private actors are embodied.
\end{abstract}

\section{Introduction}

The last 20 years have witnessed different forms of collaborative relationships that have been theorized, for example, in terms of innovation systems, innovation networks, and innovation clusters (e.g., Edquist, 1997; Freeman, 1987, 1995; Hamdouch, 2009; Lundvall, 1992; Nelson, 1993). Recently, collaboration between public and private actors has extended from production-oriented public-private partnership to include innovationoriented public-private partnership (Gallouj et al., 2013), and public-private innovation networks, or PPINs. In these new concepts, public and private organizations cooperate to access complementary cognitive resources (e.g., knowledge and technological resources, information, skills, and know-how), which are mainly employed to develop and diffuse innovation outputs.

Innovation-oriented cooperation between public and private actors has emerged, in part, due to the substan- tial growth in knowledge and technology accompanied by globalization and the invasive character of the new informational paradigm. Public-private innovation networks mobilize complex knowledge and technology to produce new artefacts or technological innovation, mainly in manufacturing sectors, where they can be more aptly described as technological public-private innovation networks, or TechPPINs. In such networks, public and private actors collaborate and interact to mobilize complex knowledge that is used to produce technological innovation.

The main objective in this work is to develop a conceptual framework to describe the working mechanism of technological public-private innovation networks that leads to efficient interactions between network members (i.e., public and private actors) and better innovation outputs. But, before proposing such framework, we briefly present an overview of the concepts of innovations networks that are intensively discussed in the lit- 


\section{Technological Public-Private Innovation Networks: A Conceptual Framework} Rabeh Morrar

erature, because they help to define the structures of public-private innovation networks and the factors that may lead to the efficient exchange of knowledge between network actors.

The second part of this article discusses the evolution of the public-private innovation network concept from public-private partnerships, to innovation networks and systems, and then to technological public-private innovation networks. In the third section, we develop a conceptual framework to understand the mechanism driving technological public-private innovation networks. A final section offers conclusions.

\section{The Conceptual Evolution of Public-Private Innovation Networks}

Public-private innovation networks have their roots in the well-known concept of public-private partnerships, or PPPs. Both concepts share a similar structure in terms of the key relationship between public and private actors.

A public-private partnership is defined as a form of cooperative venture between public and private firms (Kanakoudis et al., 2007; Moskalyk, 2008) or a contractual agreement between a public agency (e.g., federal, state, or local) and a for-profit corporation (e.g., a national council) or a new way to design, build, finance, and manage (operate) (DBFO) public building and infrastructure (Carassus, 2005). Public-private partnerships depend on public and private actors cooperating with each other to overcome budget constraints, share risk, and deliver a more cost-effective public product.

A public-private partnership is a production-oriented network: production is the main purpose of the partnership. Public institutions resort to the private sector to reduce production costs and because, in most cases, the private sector is more efficient than the public sector. Thus, innovation is not at the core of public-private partnerships, although it might emerge as a by-product of the main activity for which a production-oriented public-private partnership was set up (Gallouj et al., 2013).

The evolution from public-private partnerships to innovation networks and public-private innovation networks reveals a shift from a perspective focused on cost to a knowledge-based perspective based on evolutionary economics. The mobilization of complementary knowledge and technologies is the main purpose of in- novation networks, which emphasizes cognitive and technological objectives. In this view, Pellegrin and colleagues (2010) observe that the interactions between actors in innovation networks change from being commercial-, financial-, and production-oriented in nature to "cover a wide spectrum that goes far beyond market relations and contractual relations of cooperation".

An innovation network consists of several actors collaborating in a social, dynamic, and economic environment. This arrangement leads to "intensive communication and collaboration between different actors, private firms, and other organizations such as universities, innovation centers, educational and financing institutions, standard setting bodies, industry associations, and government agencies" (Toedtling \& Trippl, 2005), which assures the diffusion and production of innovation output.

The major motivations for the emergence of innovation networks are rapid globalization, convergence of consumer preferences, high competition for limited scientific resources (Tushman, 2004), intensive and permanent changes in technologies, and rapid developments in information and communication technologies (ICTs). All these factors have led to technological and structural deficiencies in many innovative firms and institutions, and thus local connections are becoming insufficient to solely provide the resources and competences that innovative firms might need to offset high costs and keep pace with new technologies. This trend has led to a reduction in the sustainability of the innovation processes and to major limitations on innovation in the absence of global connections to obtain knowledge and information from the surrounding environment. Therefore, organizations must enlarge their boundaries to access a wide range of corporate expertise and technological fields (Cantwell \& Santangelo, 2006; Castells, 1996), and to implement new changes to their innovation processes, taking them from a traditional to a more system-centred approach.

Substantial debate about innovation networks can be found in the literature, at theoretical (e.g., Callon, 1991; Pyka \& Scharnhorst, 2009 ), empirical (e.g., Becker \& Dietz, 2004; Morrar et al., 2013), and methodological (e.g., Pyka \& Schön, 2009; Sundbo, 2010) levels. The innovation network is an application of the non-linear or open model of innovation, and it represents a sustainable way of accessing the external knowledge and technological resources needed to produce innovations in today's environment. In other words, innovation net- 


\section{Technological Public-Private Innovation Networks: A Conceptual Framework} Rabeh Morrar

works "provide timely access to knowledge and resources that are otherwise unavailable" (Powell et al., 1996).

The evolution of the innovation network concept is "often shadowed by the recent evolution of the innovation systems concept" (Pellegrin et al., 2010), which is recognized as a broader perspective or concept that includes many of the ideas contained in other interactive innovation concepts such as, networks, clusters development blocks, complexes, innovation milieu, complex products and systems, competence blocs (Manly, 2002). The concept of innovation systems has been frequently discussed in the literature (e.g., Edquist, 1997; Lundvall, 1988, 1992; Nelson, 1993). Edquist (1997) defined a system of innovation as "all important economic, social, political, organizational, and other factors that influence the development, diffusion, and use of innovations". In contrast, Nelson (1993) defined a national innovation system as "a set of institutions whose interactions determine the innovative performance of national firms".

The discussion of innovation networks in the literature mainly highlights the role of the private sector as the main constituent element. In other words, innovation networks may be (and often are) primarily private-private partnerships. In some cases, in basic research networks, innovation networks may also take the form of public-public partnerships (Gallouj et al., 2013). But, the analysis of innovation in a particular system might require interaction or collaboration between both public and private actors (e.g., industry, government, and academia) in the production of innovation (Manley, 2002). Edquist and McKelvey (2000) highlight that the public actors are presented in the realms of public innovation policy to support and enhance innovation activities. For example, Buesa and colleagues (2006) indicate that a regional innovation system includes both public and private actors in one network and a specific area to adopt and produce new knowledge.

Thus, it is important to shed light on public-private innovation networks as an important type of innovation network, and a main source of knowledge and technological competences. The need for public-private innovation networks arises due to the increasing demand for complex networks that involve complex knowledge, sophisticated innovation practices, and the production of technological innovation and in which universities and public research centres play an important role in producing the needed knowledge and R\&D. In other words, a significant part of the complex knowledge is obtained through universities, research centres, and $R \& D$ institutions, which are defined in many countries as public bodies. In this view, technological public-private innovation networks, or TechPPINs, re-formalize the innovation networks to highlight the roles of both public and private organizations in the innovation process, and create new channels for knowledge that mainly flows through the public actors.

Many applications of technological public-private innovation networks can be found in the literature. For example, in Germany, Musiolik and Markard (2010) discussed the traditional public-private innovation networks formed between the fuel cell industry and federal governments to speed up the technology development and market formation for fuel cells. Markard and Truffer (2008) used the technological system of innovation to show the importance of collaboration between public and private agents in the generation, diffusion, and utilization of different modes of technologies and products. The EMC innovation network (tinyurl.com/ pyozbke) is also a prominent example, where research and advanced technology groups across EMC, universities, and RSA laboratories collaborate to discover and explore technologies that will shape the information infrastructure of the future. The International Development Innovation Network (IDIN; d-lab.mit.edu/idin) is a global public-private innovation network that includes: universities such as the Massachusetts Institute of Technology, the United States Agency for International Development, the United States Global Development Lab, and firms from the industrial sector. Its aim is to design, develop, and disseminate low-cost technologies to improve the lives of people living in poverty. The Nordic Health Research and Innovation Networks (NRI Networks; nordicnetworks.org) is a public-private innovation network that promotes health research and innovation in the Nordic region. It includes both public and private partners such as university hospitals (e.g., Oslo University Hospital), universities (e.g., Aalborg University and the University of Copenhagen) and other research organizations, the pharmaceutical industry, the medical technical industry, governmental bodies, and patient organizations. The European Workplace Innovation Network (EUWIN; tinyurl.com/oldm6vs) was launched in 2013 to modernize the workplace in order to create better working conditions and increased organizational performance in terms of productivity, innovativeness, and competitiveness. The network enables collaboration between members from enterprise, chambers of commerce, business federations, social partner organizations, public agencies, and research institutions. 


\section{Technological Public-Private Innovation Networks: A Conceptual Framework}

\section{Rabeh Morrar}

The literature also contains many empirical studies examining collaboration between public research and private actors (e.g., Cohen et al., 2002; Perkmann \& Walsh, 2007; Tether \& Tajar, 2008). These studies mainly focus on the actors in the network, the factors determining the collaboration, its purpose and forms, and the evaluation of its performance (Djellal \& Gallouj, 2015).

\section{Constructing the Conceptual Framework for Technological Public-Private Innovation Networks}

A conceptual framework for technological public-private innovation networks is a theoretical attempt to explain the cooperation and configuration of these networks, and to show the innovation process as an outcome of a collaborative relationship between heterogeneous public and private actors to produce new technological outputs. The theoretical framework is based on a review of literature based on general theorybridging insights from evolutionary theory, social network theory, lifecycle theory, etc. The framework expresses the dynamic process between the network actors to ensure efficient interaction that might lead to better innovation output. Empirically, this conceptual framework can be applied to describe the interaction mechanism or the innovation process in actual technological public-private innovation networks.

The conceptual framework is developed from four basic theoretical components or concepts, each of which explains an action or function. First, the framework considers the public-private partnerships for innovation between heterogeneous public and private actors in the process of technology creation and diffusion. Second, the framework considers the dynamic and evolutionary process of the interactions between the network actors (David, 1985; Nelson \& Winter, 1973), which is responsible for the network formation, or structure, over time. Third, the decoupling and fragmentation of ties within technological public-private innovation networks are enveloped by social network analysis (Cowan et al., 2004; Messica, 2007; Pyka et al., 2010), which generates knowledge disclosure between network actors and stimulates the interaction and innovation processes. Finally, the framework considers that an innovation network has an evolutionary path or lifecycle growth model (Jovanovic, 1994; Klepper, 1996, 1997; Pyka et al., 2010; Weber, 2009). In each stage of the lifecycle, new interactions are re-arranged to construct the network structure over time.

\section{The public actor role in technological public-private innovation networks}

In a public-private network, as opposed to a private-private network, the presence of public actors as key participants in the innovation process adds new complexity to the interaction process in the innovation network. Therefore, it is important to know how the relationships or interactions between the public and private actors are developed in the production and diffusion of technological innovation.

In technological public-private innovation networks, public actors are mainly involved in providing technical resources for technological innovation. Therefore, universities, public research centres, and $R \& D$ institutions are key public participants, because of their ability to provide complex knowledge and technological capabilities. Nevertheless, the public role changes from one public-private network to another, depending on the complexity of the network, the power-sharing arrangements between the public and private actors, and their relative influence on the innovation.

Public actors can also provide non-R\&D knowledge such as organizational and institutional competences (Manly, 2002). A public actor might work as an intermediate organization that provides institutional arrangements required for managing conflicts, regulating relations (i.e., cooperating), and improving the coordination mechanism between network actors. These institutional competences include new rules, routines, approaches, legal and government policies, new types of intervention tools, the design of political initiatives that foster learning and knowledge-exchange processes, and supporting functions that ensure the cross-flows of knowledge and information between other network actors.

\section{A social network analysis of technological public-private innovation networks}

Social interaction is a key process in the functioning of technological public-private innovation networks. The decoupling and fragmentation of ties (i.e., interactions) between network actors are simultaneously combined with the development of a social network (Agapitova, 2003), which means that technological innovation in public-private innovation networks is produced using social capital. In this view, the technical and economic factors alone are not sufficient to explain social interactions process in technological public-private innovation networks; a socio-economic framework is important to incorporate both technological and social dimensions of the network interaction processes. 


\section{Technological Public-Private Innovation Networks: A Conceptual Framework}

\section{Rabeh Morrar}

Generally, social capital in the networks enhances the collective learning between heterogeneous actors and impacts the exchange behaviour (Granovetter, 1985; Uzzi, 1997), which also applies to technological public-private innovation networks. In a causal mechanism related to innovation, the social proximity in the innovation network has an impact on knowledge spillovers (Coulon, 2005).

Social capital also has an important role in forging relationships, first-stage performance, and maintaining the cooperation between network actors in the long run. It is necessary to recognize the social dimension to tradeoff the deficiency when using economic dimensions to describe social entities, mainly using physical artifacts and the corresponding $R \& D$ to describe the different lifecycle stages of technological public-private innovation networks (Pyka et al., 2010).

Social network analysis is one of the most prominent techniques used to incorporate social capital in the analysis of networks (Salavisa, 2009), to describe the shape the evolution of innovation in innovation networks, and to determine the position receptivity or popularity of network actors (Wasserman \& Faust, 1994). It has been employed by many researchers in the study of innovation networks. For example, Messica (2007), in a static analysis of innovation networks in the high-technology sector used social network analysis metrics, including the clustering coefficient, the extent of the network, and connectivity, to provide a taxonomy for innovation networks. He classified innovation networks into five categories: ring, mesh, star, fully connected, and line. In a dynamic analysis of innovation networks, Cowan, Jonard, and Özman (2004) used a set of social network analysis metrics including local order (or cliquishness), path lengths, and density. They found that knowledge creation through an emerging network was the cornerstone of the innovation process. Watts (2003) used the distance between nodes to estimate the effect of network structure and the behaviour of actors. Pyka and colleagues (2010) classified social network analysis measures into two groups. The first group includes actor-related measures: degree centrality, closeness centrality, and betweenness centrality. The second group includes network-related measures to describe the structure of the whole network: density, connectivity, distance, degree distribution, and clustering.

Consequently, public-private innovation networks can be seen as social vehicles that provide the social structure for enabling the interactions between the cognitive components of the network and that facilitate the flow or exchange of knowledge and information along the network lifecycle.

\section{The dynamic aspect of technological public-private in- novation networks}

The dynamic of a network refers to the state of the network in one period determining its state in subsequent periods. Therefore, the initial form of the network has a fundamental role in the evolution of the network at later stages. It determines its final structure. The dynamic of a network should match between two network specificities: i) the enormous complexity of the interaction patterns and ii) the different incentives and information that determine the behaviour and preferences of network actors (Schweitzer et al., 2009)

In technological public-private innovation networks, the innovation process not only depends on the characteristics of the network members, but also on the interactions between them. Meanwhile, the interaction processes between network actors are dynamic (evolutionary processes) (Arechavala-Vargas et al., 2009) and are associated with ties decoupling and fragmentation processes (i.e., the entry of new actors and the exit of others) . In this view, it is important to describe or explain innovation in technological public-private innovation networks in the spirit of evolutionary theory (Nelson \& Winter, 1973), and path dependence theories (David, 1985), which describe the networks' dynamic processes. The dynamic process of an innovation network induces knowledge accumulation and learning overtime (Garcia-Pont \& Nohria, 2002; Gulati, 1999; Powell et al., 1996), and allow access to new technologies that promote the production of innovation. It also leads to different structures with different roles over time.

\section{Lifecycle growth model of technological public-private in- novation networks}

Away from the traditional view of public-private partnerships, which focus on the interaction between public and private actors in a static way, it is important to discuss the question of the public-private relationship in technological public-private innovation networks dynamically, by focusing on the lifecycle of networks (Gallouj et al., 2013).

In the literature, there are many models or approaches that describe the dynamic of the network. Li (2005) proposed a socio-cognitive model for newly developed products, which illustrates the dynamic of interaction between technological platform/hard architecture of knowledge and communities/soft architecture of knowledge that lead to open innovative and new products. 


\section{Technological Public-Private Innovation Networks: A Conceptual Framework}

\section{Rabeh Morrar}

Podolny, Stuart, and Hannan (1996) used the concept of niches in evolutionary theory and applied it to technological networks, giving rise to the notion of technological network niches. Weber (2009) proposed a theoretical model that explains the network lifecycle using chaos theory and cybernetics for public-private networks.

The network lifecycle growth model is the most wellknown theoretical concept employed to describe the growth of networks (Jovanovic, 1994; Klepper, 1996, 1997; Pyka et al., 2010; Weber, 2009). This model consists of three main stages: i) prototype industry; ii) commercialization and entrepreneurial; iii) and consolidation and firm growth.

Gallouj, Rubalcaba, and Windrum (2013) describes the lifecycle model for public-private innovation networks, which is divided into three main stages: i) the proto-industry (crystallization) stage, ii) the commercialization and entrepreneurial stage, and iii) the consolidation and firm growth stage. Each stage of the network lifecycle requires different knowledge bases, resources, actors, demands, and policies. Different modes of interaction between network actors are also expected in each stage; in other words, the exchanged knowledge to produce output " $\mathrm{X}$ " will certainly be different from that of producing output " $\mathrm{Y}$ ".

Two important points should be considered when applying lifecycle growth model to technological public-private innovation networks. First, the social dimension, which requires the introduction of "a socioeconomic approach" that consists of both economic measures (relative performance) and relevant social indicators (Cowan, 2004; Koenig et al., 2007; Pyka et al., 2010). Second, in some cases, it is difficult to follow entire stages of a network lifecycle. This difficulty might be explained by the disappearance of the network before the decline stage or the start of a new cycle within the same network (Tushman \& Anderson, 1996). In other cases, the network may follow more than one evolutionary path (Weber, 2009).

\section{A conceptual framework for technological public- private innovation networks}

Finally, we collect or summarize the previous theories in a conceptual framework that could present a clear mechanism for the interaction process between network actors that might lead to better innovation performance. This framework shows how an efficient collaboration or interaction between public and private actors is happening dynamically along the network product lifecycle, reinforced by social capital so as to have better innovation output and performance.

Within the framework (Figure 1), the innovation process proceeds as follows: the public and private actors communicate and interact between each other, where complex knowledge and technologies are exchanged between them in a collaborative environment and supported by the social capital, to produce better technological innovation output. The complementarities between actors' knowledge and technological resources are crucial for successful and efficient interaction processes. The interaction processes and the production of innovation output are dynamically evolving along the network lifecycle. In each stage of the network lifecycle, the nature of the interaction processes and innovation activities are different (e.g., the mode of innovation in the first stage of network formation is different from that at the growth or maturity stage), determined by the type of actors, the dimensions of social network analysis and the mode of knowledge and technologies that are exchanged among network actors.

Following the innovation network lifecycle developed by Gallouj, Rubalcaba, and Windrum (2013), described earlier, we expect that the role of network actors (private and public) change from one stage to another depending on the nature of required knowledge and technologies and the degree of involvement of each actors. For example, in the crystallization stage, the role of public actors represented by universities and public research centres is the most important among the other members for the initiation of innovation networks, no demand is articulated yet in this stage, and the participation of private organizations is not high. The dynamic process of the technological public-private innovation networks allows for the transition from one stage to another along the network lifecycle (e.g., from crystallization, passing commercialization, to the consolidation and firm growth phase) and shows how the competences and preferences of one actor co-evolve over time with the competences and preferences of the other network actors supported by a feedback mechanism. Network actors either reinforce each other to produce and diffuse new technological resources or, conversely, hamper each other. Social network analysis indicators are important to explain how innovation network safeguards continue the process of knowledge and technologies flowing within the network, therefore they also change from one stage to another along the network lifecycle. 


\section{Technological Public-Private Innovation Networks: A Conceptual Framework}

\section{Rabeh Morrar}

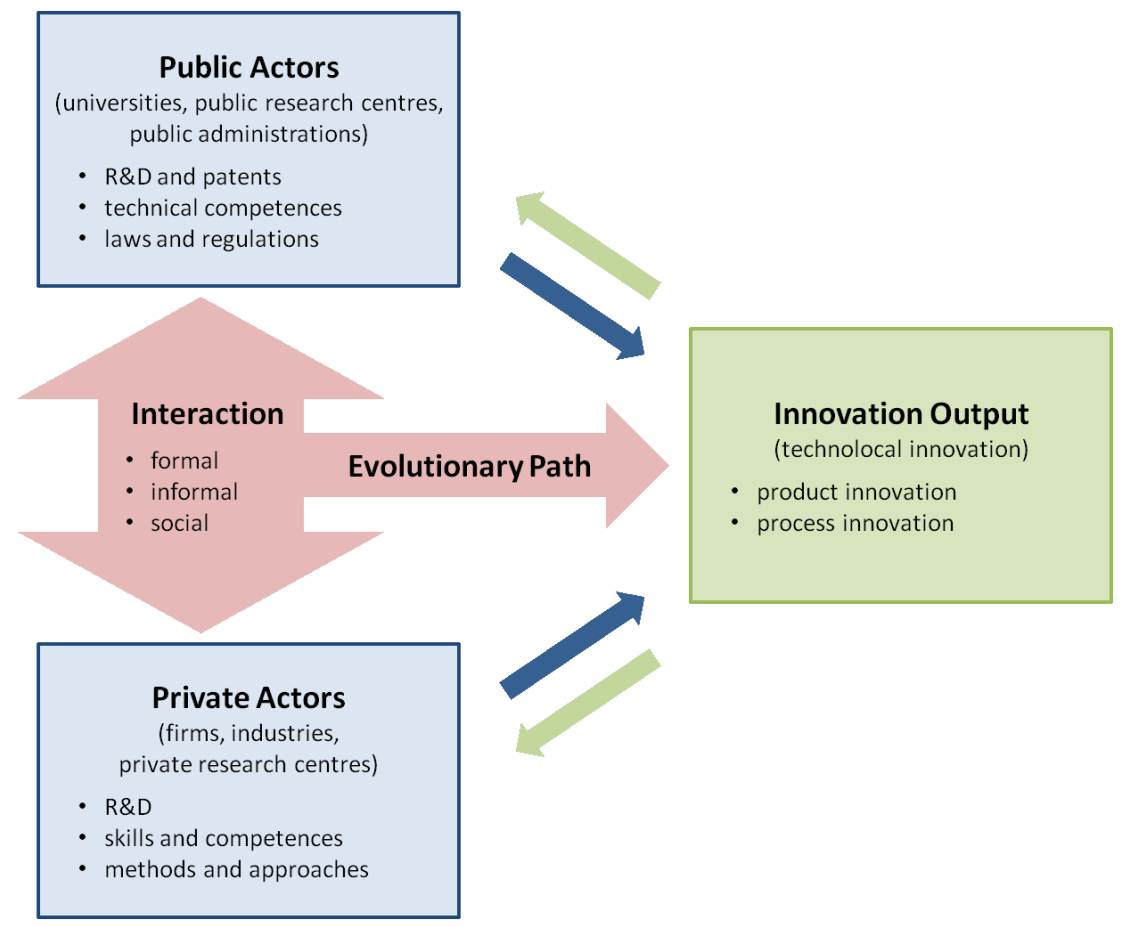

Figure 1. A conceptual framework for technological public-private innovation networks

\section{Conclusion}

In this article, we have developed a conceptual framework to account for technological public-private innovation networks. This framework accounts for the cooperation between public and private actors in a complex, dynamic, social, and interactive network structure that might lead to efficient interaction processes between network actors and might lead to better innovation outputs. In such a framework, innovation output is produced through dynamic interaction processes between the public and private actors along the network lifecycle. In each stage, various interactions occur and different modes and various quantities of knowledge and technological resources are exchanged, reinforced by the existence of social capital. The combination of the product lifecycle model and social network analysis allows us to analyze the structure of technological public-private innovation networks at each stage of the lifecycle and to reveal important information about how the roles of public and private actors are manifesting.

\section{About the Author}

Rabeh Morrar is an Assistant Professor of Innovation Economics at An-Najah National University in Nablus, Palestine. Rabeh's doctoral dissertation from Lille1 University in France focused on public-private innovation networks in the service sector, and his current research is focused on innovation in the service sector, $R \& D$ management, and technology management. Rabeh is also CEO of BEST, a small business in Palestine that provides innovation solutions and training. 


\section{Technological Public-Private Innovation Networks: A Conceptual Framework}

\section{Rabeh Morrar}

\section{References}

Agapitova, N. 2003. The Impact of Social Networks on Innovation and Industrial Development: Social Dimensions of Industrial Dynamics in Russia. Paper presented at the DRUID Summer Conference 2003, June 12-14, Copenhagen, Denmark.

Arechavala-Vargas, R., Diaz-Perez, C., \& Holbrook, J. A. 2009. Globalization of Innovation and Dynamics of a Regional Innovation Network: The Case of the Canadian Fuel Cell Cluster. Paper presented at the Atlanta Conference on Science and Innovation Policy, October 2-3, Atlanta, GA, USA. http://dx.doi.org/10.1109/ACSIP.2009.5367826

Becker, W., \& Dietz, J. 2004. R\&D Cooperation and Innovation Activities of Firms - Evidence for the German Manufacturing Industry. Research Policy, 33(2): 209-223.

http://dx.doi.org/10.1016/j.respol.2003.07.003

Buesa, M., Heijs, J., Martínez Pellitero, M., \& Baumert, T. 2006. Regional Systems of Innovation and the Knowledge Production Function: The Spanish Case. Technovation, 26(4): 463-472. http://dx.doi.org/10.1016/j.technovation.2004.11.007

Callon, M. 1991. Réseaux technico-économique et irréversibilités. In R. Boyer, B. Chavance, \& O. Godard (Eds.), Les figures de l'irréversibilité en économie: 195-230. Paris: Editions de l'Ecole des Hautes Etudes en Sciences Sociales.

Cantwell, J., \& Santangelo, G. D. 2006. The Boundaries of Firms in the New Economy: M\&As as a Strategic Tool toward Corporate Technological Diversification. Structural Change and Economic Dynamics, 17(2): 174-199.

http://dx.doi.org/10.1016/j.strueco.2005.06.001

Carassus, J. 2005. Public Private Partnership: A Service Innovation The Treasury Building Case. Paris: Centre Scientifique et Technique du Bâtiment (CSTB).

Castells, M. 1996. The Rise of the Network Society. Oxford, UK: Blackwell.

Cohen, W. M., Nelson, R. R., \& Walsh, J. P. 2002. Links and Impacts: The Influence of Public Research on Industrial R\&D. Management Science, 48(1): 1-23. http://dx.doi.org/10.1287/mnsc.48.1.1.14273

Coulon, F. 2005. The Use of Social Network Analysis in Innovation Research: A Literature Review. Paper presented at the DRUID Academy Winter 2005 PhD Conference, Conference, January 27-29, Aalborg, Denmark.

Cowan, R. 2004. Network Models of Innovation and Knowledge Diffusion. Research Memoranda 016. Maastricht: Maastricht Economic Research Institute on Innovation and Technology (MERIT).

Cowan R., Jonard, N., \& Özman, M. 2004. Knowledge Dynamics in a Network Industry. Technological Forecasting and Social Change, 71(5): 469-484.

http://dx.doi.org/10.1016/S0040-1625(03)00045-3

David, P. A. 1985. Clio and the Economics of QWERTY. American Economic Review, 75(2): 332-337. http://www.jstor.org/stable/1805621

Djellal, F., \& Gallouj, F. 2015. Services and Crisis: Stop Shooting at the Ambulance! Journal of Innovation Management, 3(1): 5-8.
Edquist, C., \& McKelvey, M. 1997. Systems of Innovation: Growth, Competitiveness and Employment. Cheltenham, UK: Edward Elgar Publishing.

Freeman, C. 1987. Technology Policy and Economic Performance: Lessons from Japan. London: Pinter.

Freeman, C. 1995. The "National System of Innovation" in Historical Perspective. Cambridge Journal of Economics, 19(1): 5-24.

Gallouj, F., Rubalcaba, L., \& Windrum, P. (Eds). 2013. Public-Private Innovation Networks in Services. Cheltenham, UK: Edward Elgar Publishing.

Garcia-Pont, C., \& Nohria, N. 2002. Local versus Global Mimetism; The Dynamics of Alliance Formation in the Automobile Industry. Strategic Management Journal, 23: 307-321.

http://dx.doi.org/10.1002/smj.225

Granovetter, M. 1985. Economic Action and Social Structure: The Problem of Embeddedness. American Journal of Sociology, 91(3): 481-510.

http://www.jstor.org/stable/2780199

Gulati, R. 1999. Network Location and Learning: The Influence of Network Resources and Firm Capabilities on Alliance Formation. Strategic Management Journal, 20(5): 397-420.

http://dx.doi.org/10.1002/(SICI)1097-0266(199905)20:5<397::AIDSMJ35>3.0.CO;2-K

Hamdouch, A. 2009. Networking, Clustering and Innovation Dynamics in the Global Economy: Features, Challenges and Open Issues. Journal of Innovation Economics, 2(4): 5-13. http://dx.doi.org/10.3917/jie.004.0005

Jovanovic, B., \& MacDonald, G. M. 1994. The Life Cycle of a Competitive Industry. Journal of Political Economy, 102(2): 322-347.

http://www.jstor.org/stable/2138664

Kanakoudis, V., Podimata, M., and Papotis, A. 2007. PPPs in the Renewable Sources Energy Sector: The Greek Experience of a Medium-Scale Hydropower Plant. European Water, 17/18: 41-49.

Klepper, S. 1996. Entry, Exit, Growth, and Innovation over the Product Life Cycle. American Economic Review, 86(3): 562-583. http://www.jstor.org/stable/2118212

Klepper, S. 1997. Industry Life Cycles. Industrial Corporate Change, 6(1): 145-182.

Koenig, S., Battiston, M., Napoletano, F., \& Schweitzer, F. 2007. On Algebraic Graph Theory and the Dynamics of Innovation Networks. Networks and Heterogeneous Media, 3(2): 201-219.

Li, J. 2005. Unleashing Innovation: A Socio-Cognitive Approach. Paper presented at the Druid Tenth Anniversary Summer Conference 2005, June 27-29, Copenhagen, Denmark.

Lundvall, B.-Å. 1988. Innovation as an Interactive Process: From UserProducer Interaction to the National System of Innovation. In G. Dosi, C. Freeman, R. Nelson, G. Silverberg, \& L. Soete. (Eds.), Technical Change and Economic Theory: 349-369. London: Pinter.

Lundvall, B.-Å. (Ed.). 1992. National Systems of Innovation: Towards a Theory of Innovation and Interactive Learning. London: Pinter.

Manley, K. 2002. The System Approach to Innovation Studies. Australian Journal of Information Systems, 9(2): 94-102. 


\section{Technological Public-Private Innovation Networks: A Conceptual Framework}

\section{Rabeh Morrar}

Markard, J., \& Truffer, B. 2008. Technological Innovation Systems and the Multi-Level Perspective: Towards an Integrated Framework. Research Policy, 37(4): 596-615.

http://dx.doi.org/10.1016/j.respol.2008.01.004

Messica, A. 2007. Innovation Networks Taxonomy and Efficiency Toward Innovation Engineering. Holon, Israel: Center for Entrepreneurship and Innovation Management, Holon Institute of Technology.

http://dx.doi.org/10.2139/ssrn.1023964

Morrar, R., Gallouj, F., \& Hammadou, H. 2013. Public-Private Innovation Networks and Innovation Activities in French Service Sector. Journal of Innovation Economics \& Management, 10(2): 191-217.

Moskalyk, A. 2008. The Role of Public- Private Partnerships in Funding Social Housing in Canada. Ottawa, Canada: Canadian Policy Research Networks.

Musiolik, J., \& Markard, J., 2010. Innovation Networks and Resources in Technological Innovation Systems: Insights from the Field of Stationary Fuel in Germany. Paper presented at the DRUID-DIME Academy Winter 2010 PhD Conference, January 21-23, Aalborg, Denmark.

Nelson, R. R. (Ed.) 1993. National Innovation Systems. A Comparative Analysis. Oxford, UK: Oxford University Press.

Nelson, R. R., \& Winter, S. 1973. Toward an Evolutionary Theory of Economic Capabilities. American Economic Review, 63(2): 440-449. http://www.jstor.org/stable/1817107

Pellegrin, I., Balestro, M. V., Júnior, J. A. V., \& Vaz Dias, S. L. 2010. Dynamizing Innovation Systems through Induced Innovation Networks: A Conceptual Framework and the Case of the Oil Industry in Brazil. Journal of Technology Management \& Innovation, 5(3): 15-35.

Perkmann, M., \& Walsh, K. 2007. University-Industry Relationships and Open Innovation: Towards a Research Agenda. International Journal of Management Review, 9(4): 259-280. http://dx.doi.org/10.1111/j.1468-2370.2007.00225.x

Podolny, J. M., Stuart, T. E., \& Hannan, M. T. 1996. Networks, Knowledge, and Niches: Competition in the Worldwide Semiconductor Industry, 1984-1991. American Journal of Sociology, 102(3): 659-689.

http://www.jstor.org/stable/2782460

Powell, W. W., Koput, K. W., \& Smith-Doerr, L. 1996. Interorganizational Collaboration and the Locus of Innovation: Networks of Learning in Biotechnology. Administrative Science Quarterly, 41(1): 116-145. http://www.jstor.org/stable/2393988

Pyka, A., \& Scharnhorst, A. (Eds). 2009. Innovation Networks: New Approaches in Modelling and Analyzing. Berlin: Springer-Verlag.
Pyka A., \& Schön, A. 2009. Taxonomy of Innovation, Cooperation and Networks in Service Industries. ServPPIN Project, European Commission.

Pyka, A., Schon,, B., Triulzi, G., Windrum, P., Filiou, D., Frenken, K., Sundbo, J., Sceuer, J., \& Fuglsang, L. 2010. Cooperation for Innovation in Services: Taxonomy of Innovation, Cooperation, and Networks in Service Industries. ServPPIN Project, European Commission.

Salavisa, I. 2009. Entrepreneurship and Social Networks in IT Sectors: The Case of the Software Industry in Portugal. Journal of Innovation Economics, 2(4): 15-39.

Schweitzer, F., Fagiolo, G., Sornette, D., \& Vega-Redondo, F. 2009. Economic Networks: What Do We Know and What Do We Need to Know? Advances in Complex Systems, 12(4-5): 407-422.

Sundbo, J. 2010. Public-Private Networks and Service Innovation in Knowledge Intensive Services: A Report of European Case Studies. ServPPIN Project, European Commission.

Tether, B., \& Tajar, A. 2008. Beyond Industry-University Links: Sourcing Knowledge for Innovation from Consultants, Private Research Organisations and the Public Science-Base. Research Policy, 37(6-7), 1079-1095. http://dx.doi.org/10.1016/j.respol.2008.04.003

Toedtling, F., \& Trippl, M. 2005. One Size Fits All? Towards a Differentiated Regional Innovation Policy Approach. Research Policy, 34(8): 1203-1219. http://dx.doi.org/10.1016/j.respol.2005.01.018

Tushman, M. L. 2004. From Engineering Management/R\&D Management, to the Management of Innovation, to Exploiting and Exploring over Value Nets: 50 Years of Research Initiated by IEEETEM. IEEE Transactions on Engineering Management, 51(4): 409-411. http://dx.doi.org/10.1109/TEM.2004.836365

Tushman, M. L., \& Anderson, P. 1996. Technological Discontinuities and Organizational Environments. Administrative Science Quarterly, 31(3): 439-465. http://dx.doi.org/10.2307/2392832

Uzzi, B. 1997. Social Structure and Competition in Interfirm Networks: The Paradox of Embeddedness. Administrative Science Quarterly, 42(1): 35-67. http://dx.doi.org/10.2307/2393808

Wasserman, S., \& Faust, A. 1994. Social Network Analysis: Methods and Applications. Cambridge, UK: Cambridge University Press.

Watts, D. J. 2003. Six Degrees: The Science of a Connected Age. New York: Norton.

Weber, M. 2009. Public Private Innovation Network in Transport. Servppin Project, European Commission. 